\title{
An Exploration Into Leadership Practice in Madrasah Aliyahs (Islamic-Based Senior High Schools) in Indonesia
}

\author{
Didin Nuruddin Hidayat \\ State Islamic University Syarif \\ Hidayatullah Jakarta, Indonesia \\ didin.nuruddin@uinjkt.ac.id
}

\author{
Ummi Kultsum \\ State Islamic University Syarif \\ Hidayatullah Jakarta, Indonesia \\ ummiwahyudi@gmail.com
}

\author{
Ting Wang \\ University of Canberra \\ Canberra, Australia \\ ting.wang@canberra.edu.au
}

\begin{abstract}
This study investigates how principals exercise leadership to tackle the difficulties faced by Islamic Senior high schools or Madrasah Aliyahs of three areas in Indonesia: Western, Central and Eastern Indonesia. Employing qualitative methods, the researchers applied multiple case studies technique. The information gathered originated from separate case study classrooms, purposefully chosen madrasah Aliyahs/ Islamic-based high school from government, private, challenging and high-performing schools. It has been disclosed that madrasahs experience countless difficulties, including leadership, curriculum development, classroom equipment, financing and teacher efficiency. In the west and center of Indonesia, madrasahs mainly hampered by the poor infrastructure, learning facilities and lack of financial support, while in the east part beside the financial issues, teachers' performance become huge concerns.The madrasah managers, senior institutional officials, have a critical part to perform in solving these issues, in particular by developing teaching and learning procedures and improving the value of education and the enhancement of schooling. The study found that a kinship leadership is strongly indicated to the principal leadership behaviour. A culture embedded, leadership education, and experience gained by the leaders provide a deep insight on the way they lead an organisation. Although some madrasah adapted professional system like in the case of some high performing schools, the kinship and partnership are strongly occupied by the leaders in order to develop their communication and interaction among the members
\end{abstract}

Keywords: madrasah Aliyah, school principal, leadership, education

\section{INTRODUCTION}

Since its inception in the postwar era of twentieth century,Islamic-based schools have become a significant component of the Indonesian education scheme[1]. Its existence is needed for most $95 \%$ Indonesian Muslim society. However, madrasah performance still faces challenges that hinder its development. Some issues such as financial, infrastructure, facilities, leadership, teacher performance, and community need to be addressed. However, from all factors, leadership would be the core point to move madrasah in a better way.

In Indonesia, madrasahs leadership will be heavily rely on a school leader. The Principal of the School is an organizational chief who runs the institution and regulates the teaching and learning system. In addition, the Principal encourages employees to keep dialogue and engagement within the organization [2]. Consequently, the problems encountered by Islamicbased school/ madrasah Aliyah have become major difficulties for the students to solve. Especially the principal should directly engage on the following concerns:

\section{A. Curriculum}

As Islamic Institution, the madrasah centers Islamic-based education in its curriculum. $30 \%$ of topics learned in madrasah Aliyah are Islamic topics, including Tauhid (Monotheism), Aqeedah (Islamic Morals), Islamic Jurisprudence and the Islamic Holy Book (Al-Quran). The rest $70 \%$ of topics are conventional sciences, like English, physics and mathematics. The mixture of such two subjects creates a number of difficulties. The large amount of topics learned in madrasahs decreases the efficiency of its teaching-learning method [3]. In addition, the normal courses for religious and conventional disciplines are very distinct.Religious topics have adjusted Curriculum 2013 technique, which gives priority to character building. This implies that all topic content should comply with the requirements for character education set out in the mentioned curriculum. Nevertheless, secular topics are focused on such a curriculum developed from the Ministry of National Education (MoNE) named the "SBC" or School-based Curriculum (KTSP) to which understanding is the center of teaching. Some issues occur because SBC/ KTSP is established on the basis of classroom requirements, whereas the Curriculum 2013 has been established by central administration. Educational employees, as well as for teachers or even managers, need to operate easier to manage both the curricula[4].

\section{B. Learning Materials}

Teaching materials present extra difficulties in the Islamic school/ madrasah for its instruction and learning system. These problems mainly concern private Islamic school/ madrasahs. The state offers the courses needed by learners across all public madrasas. They do not, however, provide these facilities to private Islamic school/ madrasahs. This was because 
private Islamic school/ madrasahs are deemed to be personal entities requiring autonomous financing. Support in the manner of the supply of teaching equipment is therefore not considered to be the obligation of the state. The textbooks for learners in private Islamic school/madrasahs are therefore financed by the dependent of the students.Nevertheless, the majority of the pupils in the private Islamic school/madrasahs came from mid to lower-income category; therefore, most cannot possibly afford the textbooks required[5]. Regrettably, organizations like those of USAID, AusAID and ADB help to give textbooks required in the madrasah in Indonesia. Even so, they mainly supply textbooks for conventional disciplines such as Mathematics or English [6].

\section{School Facilities and Infrastructure}

Some of the Islamic school/ madrasahs are experiencing difficulties in terms of school equipment and facilities. It is also an issue which is more common in private Islamic school/ madrasahs. This is indeed a major problem, since classroom equipment, such as computers, laboratory for biology and others, are a critical component of the teaching system[7] [8]. Furthermore, it has been discovered that certain madrasahs/ Islamic school have a restricted amount of classrooms, requiring learners to take turn often to access the services. Some global donors have tried to promote madrasah infrastructure. But again, this assistance did not address all the expenses of madrasahs/ Islamic school; as a result, several madrasahs/ Islamic school have inadequate teaching equipment.

\section{Financial Management}

The strategy of decentralization in education has been implemented as of 2001[9]. This stripped the madrasahs/ Islamic school of the ability to run the schools. The beneficial effect of this strategy is that Islamic school/ madrasahs can initiate modification to enhance their organizations on the basis of the requirements of host culture. In some conditions, this independence could force madrasahs to enhance their performance in order to contend with the other Islamic school/madrasahs or other conventional schools. They ought to search, assign, prioritize, handle and assume accountability for their own autonomy. This may have an impact on the financial planning of the madrasah. At such a point, the national government has assigned financing to promote both public as well as private madrasas.Previous financing has, however, been assigned to teachers ' salaries, since there are more honorary teachers than public staff educators. For private Islamic-based senior high schools, this problem is a much higher undertaking because their operating cost depends on self-financing.

\section{E.Teacher Development}

Past studies show that plenty of teaching-learning problems in Islamic-based senior high schools/ madrasahs correspond to student efficiency [10][11]. This is indeed a major task, as Islamic school/ madrasahs mainly have a shortage of human resources. Incompetent teachers in charge of a discipline may lead in a lower level of learning. One of the notable research finding reported information of 90,441 teachers of Islamic school/ madrasah Aliyahs where only 65,073 (72\%) had undergraduate education or greater qualification, whereas 25,368 (28\%) had no any bachelor degree[12]. As for all the teachers who poses bachelor degree, some of them are in charge of the subject that are not linked to their credentials. This could have a negative impact on teaching-learning process.

With all of the five issues listed above, a school principal/ manager in the madrasahs/ Islamic school should have the leadership ability to tackle the challenges. First, as far as curriculum design is concerned, the madrasah headmaster must handle and enforce two distinct curriculum, each with its own distinct teaching intent [13] [14]. The curriculum 2013 becomes focused on character building and also has a cultural theme. Thereby, one of the objectives of Curriculum 2013 is to develop pupil personalities centred on the principles and culture of the fields in which they reside. For this reason, MoRA adjusted the idea of the Curriculum 2013 for religious topics. Likewise, KTSP (operated by MoNE) focuses on pupil understanding. The teaching method relies on how learners understand and evaluate it with a test. As a consequence, madrasah/ Islamic school teachers and headmaster have the biggest responsibility for satisfying the curriculum demands.

Second, in handling the madrasah/ Islamic school, a principal has some significant duties, including creating a school mission and vision, establishing organizational goals, offering funds to help the teaching method, overseeing and assessing students, retaining the performance of employees, and ensuring efficient interaction and engagement between personnel employees [15]. That become peculiar difficulties for madrasah/ Islamic school managers as it lack equipment and financing [16][17].

Third, depending on the qualifications of teachers as well as the performance of Islamic-based senior high schools, some researches have shown that the teachers in madrasah were not sufficiently competent to educate particular topics because they have bad understanding of teaching instruments and restricted capacity with the techniques needed to promote learning [18]. Teacher efficiency is an important component of enriching teaching results. Teachers are the primary component of education that enables learners comprehend the topic. Empirical research 
indicate that performance education has a significant impact on pupil performance [19][20].

Effective teaching needs teachers to organize the school and produce material efficiently [21]. Finally, as a manager, the headmaster should take on the creation of the teacher as portion to her or his duties. MoNE points out that the school leaders should guide the organization and optimize personal capital. Practical management abilities will allow alternatives to be identified and implemented to improve the performance of educational employees in Islamic school/ madrasah Aliyahs. For example, a headmaster may explore new designs of teaching and communicate or discuss it with the teachers in order to enhance learning performance [22].

Past study on Islamic school/madrasah principals in the development of teachers' competence[23], curricula [24]and management [25] underlies the main attempts in the negation of madrasah problems. However, they have not investigated important behaviors and methods implemented by school principals to tackle the difficulties. This research will therefore provide a fresh knowledge and perspective into the essence of management practices in madrasah/ Islamic school's education.

\section{F. Literature Review}

The fundamental concept of management includes two tasks: giving orientation and exerting impact [26]. Delivering instruction is how a manager utilizes her or his capacity to provide advice to members to attain an organizational goal. In the same time, it is also the exercise of the impact of the managers on the supporters. Such two characteristics can be used to perceive the behavior of the supporters, to designate the view of the organization, to organize practices to achieve the objectives of the system, to encourage members, to retain team affairs and to cultivate relationships with people and organizations outside of the organization.

In Indonesian framework, the managers of an organisation have a significant management position to play in enhancing classroom efficiency. Policy, interaction and engagement will have a major impact on the efficiency of continuing operations in classrooms [27]. A research by Muhammadishowed there is an important correlation between the management of the teachers and the achievement of the school[28]. The research discovered that efficient management can promote the incentive of the employees to operate efficiently. Another research undertaken discovered that the retention of the teaching system necessitates a strong teaching organization and leadership of the performance teaching system, which relates to practice management in the performance of their responsibilities and tasks as leaders[29]. School administration can function well if the leaders in the
Islamic school/madrasahs exercise efficient leadership.

According to a research, some styles of leadership that could be applied in any organization including those in madrasahs as an educational organisation may be identified in five categories as: 1) Transactional Leadership; 2) Transformational Leadership; 3) Post-Transformational Leadership; 4) Moral Leadership; and 5) Instructional Leadership[30]. However, for the purpose of this study, the type of leadership will be extended into the following category:

\section{G. Indigenous Leadership}

A major difference of leadership practice between west and east is the tradition where religion, beliefs, wisdom, and family are oriented in managing the organisation[31]. In the Indonesian context, the indigenous concept of leadership tends to connect with two cultural values including religious values and basic moral [32]. As a multicultural country, Indonesian has unique local cultures and wisdom. However, people of Indonesian concern their life with the religion belief where it becomes the significant rule of a daily life [33]. As a result, the religions influence the cultures of Indonesia. There are at least five religions in Indonesia including Hindu, Buddha, Christian, Confucian, and Islam [34].

The cultural and religious understandings of Indonesian have created their characters which hooked in their beliefs. Therefore, it may influence their way of thinking, attitude, and behaviour. For instance, the culture in some areas of Indonesia like Sumatra, Aceh, and Java have been significantly influenced by Islam where the religion is majority's beliefs in the area. On the other sites, some areas like Maluku, Southeast Nusa, and Papua are influenced by Christian and Bali is influenced by Hindu.

The indigenous leadership, at this stage, promotes religions and cultures that are embedded in a leader. The religion itself has a wide force to create the unique influence to the values, attitudes, and character of a leader or an environment in which they share the same belief [35]. A leader who is nurtured with good religious knowledge and guidance, for example, will almost certainly carry his or her religious character into leadership practice. Eventually, his or her style of religious leaders will create a religious work environment. The religious environment will provide a positive value in the management of madrasahs. Then, Madrasahs may deliver the values into the educational programs. On the other words, organisational culture is more superficial than societal culture. It is strongly influenced by societal culture [36]. Therefore, the cultural values in an organisation may or may not align with societal culture. 


\section{H. Kinship Leadership}

The academic discussion about kinship and leadership practice in is very rare. Some sociological and business scholars tended to describe the kinship as the family relationship such as mother, father, children, and siblings [37]. In an indigenous theory, kinship described as family, clan, and individuals who have tried to engage in one purpose like business or commerce [38]. From all approaches, it can be understood that the basic understanding of kinship is a system prescribes how people living together should interact with another [39]. A kinship relationship concerned on the development of emotional connection to strengthen the relationship among the group [40].

In the context of leadership practice, the kinship leadership expresses the kin-based relationship between heads and followers. The kinship leadership starts from equality in community, language, culture, habits, and religion creates a sense of unity and principle in running the organization [41]. The ancestral cultural heritage influences a lot to the practice of leadership in an organisation. For example, the Ecuador leadership foundation obtained a huge influence from Inca society. The leadership context employs military prowess, divine right, and kinship [42]. In the Indonesia context, a kinship leadership strongly influenced by cultural understanding based on the geographical setting. However, Indonesian distinctive values such as friendly society, welfare system, and life assurance are included generally in each culture [43]. It is stated that Indonesia society is friendly, open-handed, and tolerant. This character influence on the Indonesian leadership performance [44]. It is argued that the leader in an organisation in Indonesia as a role as a father who is expected to behave wisely and honesty [45]. Further, an Indonesian leader has moral responsibilities that influenced by their ethical qualities and religious yearnings. Therefore, the leadership practice in Indonesia culture maintain their responsibilities both in task and relationship with their people [46].

\section{Principal-Teachers Interaction}

Engagement among school principals and instructors is like a symbiosis of mutuality; all sides offer and embrace benefits. For principal, communication can provide data, assessment and alternatives that can assist them retain the performance of the school. Mutual relationships may also help educators to retain elevated efficiency expectations and enhance pupil results. Positive relationships between leadership and employees allow for powerful and transparent interaction, which helps to avoid conflict. Teachers, for instance, will not feel assessed by the school principal during teacher evaluations because they realize that the future advantages to their career development can be
achieved.The empiric research looked at the assessment of educators and how school principals ensure teachers ' confidence [47]. In this studies, the principals did not fully monitor or assess the efficiency of educators in the classroom. Rather, the school principal chose to communicate their feelings in order to stimulate and foster the teachers. The Principal made it easier for all the teachers to communicate any ideas or thoughts, so that all teachers could create their own perspectives and findings. In this research, self-reflection is considered to be more efficient than the assessment undertaken by others.

As in many organizations where the type of leadership should be relevant to lead the group towards achieving organizational objectives, in madrasahs, the principal should have the kind of leadership that is advisable with the background, circumstances and cultural characteristics of the madrasahs. Effective management is required at this point to impact classroom achievement and cause enhancement [48]. Many research have shown that efficient management contributes to classroom enhancement [49][50].

\section{METHOD}

A multiple case study method has been used by in the present studies. The information gathered originated from separate case study institutions, i.e. deliberately chosen madrasah Aliyahs/ Islamic-based senior high schools from government, private, low and high-performing schools in three areas of Indonesia; Western, Central and Eastern part. Information were gathered at the place where the respondents encountered the study problem. In this research, West part of Indonesia includes Bengkulu, Banten and West Java, Central part of Indonesia includes Sulawesi and Kalimantan, and East part of Indonesia includes North Maluku and Papua. A sum of 14 Islamic school/ madrasahs were chosen in western, central and eastern Indonesia. In the meantime, the selected participants consisted of 9 people in each school: one headmaster, the vice principals of curriculum, and 7 teachers, with a sum of 126 respondents. They were surveyed to report their perception of leadership exercise, classroom management, and teacher achievement in the Islamic school/ madrasah.

In order to analyze the information, the researchers used systematic analysis to define the study objective of the management exercise at Islamic school/ Madrasah Aliyahs. It needs researchers to define and group the datasets centred on main classifications. Primarily, researchers will identify and analyze the topics throughout the data set in order to reply study concerns. Due to the effectiveness of the analysis of large information from various case studies, it emphasized the optimization of the instruments rather than the use of some kind of 
techniques[51]. This study introduced conceptual networks and evaluation instruments modelled on Attride-Stirling's hypothesis (2001), with the previous sections of conceptual networks systemizing the removal of: (a) the lowest-order grounds apparent in the document (or fundamental topics) ; (b) the classes of fundamental topics gathered together to summarize conceptual values (organizing topics) ; and (c) superordinate topics that encapsulate the leaders ' metaphors in the document as a whole (or worldwide topics)[52].

\section{FINDINGS AND DISCUSSION}

Each part of Indonesia holds a distinct peculiar leadership behavior of principal on managing madrasahs, mainly due to the unique characteristics of each region holds and the concentration of the problems a madrasah faces. The following will elaborate the finding of the research based on the regions

\section{A. West Indonesia}

The findings from West zone of Indonesia indicate that all madrasah still has challenges. However, the leadership role in each madrasah showed the features to address those challenges. Kinship leadership might the representative model which is mostly adopted by school leaders in West Indonesia. It can be found that leaders as listeners, family, parents, and partner represent the kinship interaction in the madrasah.

For the low performing madrasah including one school in Banten and one school in West Java for instance, they were still struggling on developing the infrastructure and learning facilities. The weak financial sources and management indicated the weak support on school maintenance and teacher's improvement. An ineffective leadership practice and conflict between foundation and teachers in private madrasahs and a delicate communication and interaction between leader and followers become a significant struggle for the leadership practice in the schools in west area.

On the other hand, other four madrasahs in which have been categorized as high performing and developed madrasah Aliyah both in South Tangerang and Bekasi, West Java were found to have some positive aspects which support their performance. The first aspect is kinship leadership practice which adopted mostly by the leaders. Leader as a parent and members as a family and partners have described clearly in the organisation. For instance, in 1 school in South Tangerang, school members treated the principal as their father. His attitude and moves are a role model for his followers. Any interaction developed as a father and children communication. Although all the madrasahs have a well-organised working system, the kinship approach is prioritised to create the relationship and solving the conflict in the organisation.
The second aspect is teacher development. It was found that the developed madrasahs indicate to maintain teacher performance by giving them enough training and learning including providing the scholarship for the teacher who was willing to continue their magister degree (case of madrasahs in South Tangerang). The madrasahs also offer teacher training both inside and outside of the school (four case study). Moreover, a teacher consortium also facilitate teachers to gain their knowledge regarding their field of teaching. The third factor is a splendid working system which support good management in the madrasahs. For instance, the madrasah in BekasiWest Java case study showing a properly working system. They design three working groups with a different task. The grouped namely ring one, two, and three. Those group work in synergy and complete one to each other. The leader as this stage provides support and control to the process of the system. The last aspect is the madrasah create a distinctive, creative, and innovative learning strategy. Madrasah in South Tangerang develop a learning approach through music and sport which those strategies might invite student intelligence. The same idea is also implemented in Madrasah in Bekasi where the school provide musical studio and massive sports hall to facilitate student passion on the two hobbies. Slightly different from the two madrasahs, the other case in South Tangerang madrasah created an innovation of learning strategy by developing the research performed school. At this stage, the students are treated to research solving the learning problems. The aim of the strategy is the learning product that produced by students. Some academic articles and science projects appeared as proof of the success of the program.

There are at least three improvement factors influence the emerging madrasah. First, leadership practice in the school indicates the good management of the school infrastructure, financial, and teacher performance. The kinship leadership applied in the organisation. The leaders tend to serve and facilitate their followers to deal with the new concept of the school working system. The digitalised working system in some circumstances challenge the teachers to adjust with it. At this stage, the school leaders including principal and deputies present as guidance and work together with the followers to reach the goal of the organisation.

\section{B. Central Indonesia}

Regarding leadership practice in madrasah aliyah in central Indonesia, the researchers found that there was not an explicit statement from principals in the sample of the study. However, from the observations, it clearly described that principals put themselves as a role model for their followers. The case of madrasah in Makassar for instance, the principal tended to open himself receiving any opinion and feedback from his followers. He stressed that any method will be chosen 
to avoid the conflict in an organisation. Treating them as a family is one of a strategy to attach develop a sense of belonging among the members. In the other word, kinship leadership clearly apply in the leadership practice in madrasah aliyah in central Indonesia.

However, the two madrasahs in the sample of this research are located in a rural area in central Indonesia. This condition seems to affect the teaching-learning development. The massive changes of curriculum and limited socialisation from central government affected the slow adjustment for teacher and student to the new learning concept. For instance, some senior teachers in Balikpapan stated that the recent curriculum provided more challenge. They complained that the new curriculum forced them to deal with technology utilization and online working. As a result, some of them refused to adopted it and stick with the previous curriculum. A senior teacher mentioned that the earlier curriculum is more handy and easier to be operated compare with the new one.

A low teacher performance of madrasah aliyah in central Indonesia also necessary to be addressed. The study found that the both sample madrasahs in Makassar and Balikpapan hired some low-quality teachers. It definitely would impact to their teaching and learning quality. There were at least two reasons why teacher performance became an issue. First, a little interest on teachers and staff to teach in Islamicbased senior high schools. In madrasah I Balikpapan, for instance, the low number of teachers constrained the madrasah to borrow some teachers from Ministry of National Education (MoNE) to support other teachers. The principal stated that from thirty-nine teachers of madrasah, thirteen of them are hired from MoNE. Second, based on researcher observation, there were more senior (old) teachers who taught in the madrasah. Therefore, an old fashion of teaching strategy like 'chalk and talk' tended to be applied. They reluctant to upgrade their teaching style. Consequently, students found learning was tiring and boring.

\section{East Indonesia}

Most of madrasahs in east Indonesia face almost same challenges such as lack financial support from government, weak leadership, and cultural understanding. The main factor of the issue is madrasah's geographical situation. Those madrasahs set in the rural area which limit some distribution like logistic, budget, and information from central government. Although the madrasah sample in this research are categorised as high performing public madrasah aliyahs based on National Board Accreditation of school and madrasah (BAN S/M), they claim that their performance is still lower than other madrasah in urban area especially madrasah in Java island.
Their assertion that there is no appropriate financial support from government is the main issue of the madrasah performance. The principal in madrasah sample in West Papua stated that the budget distribution from government is not optimal. Consequently, the lack of budget hinders some implication of the school program. Furthermore, the principal also complains that government fund never meets the school needs. Therefore, in some circumstances the madrasah should propose some loans from personal sponsor to reach the goal of the school. The similar problem is also happening in madrasah sample in Ternate. The government financial support is too small since the school has small number of students. It got worse by the situation where there is some tension arise among members of the school which cause an ineffective teacher working performance. A permanent teacher of the sampled madrasah in East area stated that a weak leadership performance may influence the issue.

Cultural understanding also become an issue found in this zone like Madrasah Aliyah in West Papua. In the case of the teachers tension the participants of the research mostly highlighted that it was caused by their cultural backgrounds. They mostly come from FakFak, Biak, and Sorong which describe different culture and habit. The tension exists caused by some miss-communication and interpretation that appear among them. Ideally, the principal can see and address the issues. However, it might difficult for a principal to deal with it since cultural background already becomes their character.

\section{CONCLUSION}

As a key leader, madrasah principals take a significant role to bring the institution and members in a better performance. Therefore, to reach the goal, a leader needs to have a leadership skills and experience. However in the context of Indonesia, the study found that a kinship leadership is strongly indicated to the principal leadership behaviour. A culture embedded, leadership education, and experience gained by the leaders provide a deep insight on the way they lead an organisation. Although some madrasah adapted professional system like the one found in West zone the kinship and partnership are strongly occupied by the leaders in order to develop their communication and interaction among the members. Some kinship leadership such as leaders as parents, members as family, partnership, appreciation, friendship, cooperation, and ownership are found from those case studies. This kinship leadership style would be a character of Indonesian leadership that it is suitable with Indonesian culture.

\section{REFERENCES}

[1] Parker, L., \&Raihani, R. (2011). Democratizing Indonesia through education? Community participation in Islamic schooling.Educational Management Administration \& Leadership, 39(6), 712-732. 
[2] Jawas, U. (2017). The influence of socio-cultural factors on leadership practices for instructional improvement in Indonesian schools. School Leadership \& Management, 1-20

[3] Tan, C. H. P. (2014). Educative tradition and Islamic-based senior high schools in Indonesia. Journal of Arabic and Islamic Studies (JAIS), 14(2014), 17

[4] Marlina, M. E. (2013). Kurikulum 2013 yang Berkarakter. JPIIS: Jurnal Pendidikan Ilmu-ilmu Sosial [Online], 5(2).

[5] Muhajir. (2016). The implementation of Madrasah-Based Management (MBM) at MAN 1 and MAN 2 Serang City, Banten, Indonesia-A Comparative Study. Higher Education Studies, 6(2), 11.

[6] ADB. (2006). Indonesia: Madrasah Education Development Project. Jakarta.

[7] ADB. (2006). Indonesia: Madrasah Education Development Project. Jakarta

[8] Muhajir. (2016). The implementation of Madrasah-Based Management (MBM) at MAN 1 and MAN 2 Serang City, Banten, Indonesia-A Comparative Study. Higher Education Studies, 6(2), 11.

[9] Muhajir. (2016). The implementation of Madrasah-Based Management (MBM) at MAN 1 and MAN 2 Serang City, Banten, Indonesia-A Comparative Study. Higher Education Studies, 6(2), 11.

[10] Ahid, N. (2014). Problem Pengelolaan Madrasah Aliyah dan Solusinya. ISLAMICA: Jurnal Studi Keislaman, 4(2), 336353.

[11] Komariah, A. (2016). Authentic leadership behavior in madrasah aliyah in Tasikmalaya Regency. Jurnal Pendidikan Islam, 1(3), 407-422.

[12] Muhajir. (2016). The implementation of Madrasah-Based Management (MBM) at MAN 1 and MAN 2 Serang City, Banten, Indonesia-A Comparative Study. Higher Education Studies, 6(2), 11.

[13] Azra, A. (2014). Reforms in Islamic education: A global perspective seen from the Indonesian case. Reforms in Islamic Education: International Perspectives, 59.

[14] Tan, C. H. P. (2014). Educative tradition and Islamic-based senior high schools in Indonesia. Journal of Arabic and Islamic Studies (JAIS), 14(2014), 17.

[15] Wildy, H., \& Dimmock, C. (1993). Instructional leadership in primary and secondary schools in Western Australia. Journal of Educational Administration, 31(2).

[16] ADB. (2006). Indonesia: Madrasah Education Development Project. Jakarta

[17] Muhajir. (2016). The implementation of Madrasah-Based Management (MBM) at MAN 1 and MAN 2 Serang City, Banten, Indonesia-A Comparative Study. Higher Education Studies, 6(2), 11.

[18] Ahid, N. (2014). Problem Pengelolaan Madrasah Aliyah dan Solusinya. ISLAMICA: Jurnal Studi Keislaman, 4(2), 336353.

[19] Darling-Hammond, L. (2008). Teacher learning that supports student learning. Teaching for intelligence, 2(1), 91-100.

[20] Gess-Newsome, J., Taylor, J. A., Carlson, J., Gardner, A. L., Wilson, C. D., \& Stuhlsatz, M. A. (2016). Teacher pedagogical content knowledge, practice, and student achievement. International Journal of Science Education, 120.

[21] Byker, E. J., Xu, T., \& Chen, J. (2016). Teacher Quality in the Twenty-First Century: Developing Globally Competent Teachers. In Handbook of Research on Professional Development for Quality Teaching and Learning (pp. 496516): IGI Global.

[22] Heck, P. H. a. R. H. (2011). Leadership and Students Learning Outcomes In J. R. a. H. Timperley (Ed.), Leadership and learning (pp. 245). London: Sage Publications Ltd.

[23] Muhammadi, N., Marzuki, S. C. b. H., \& Hussin, M. Y. b. M. (2017). Kepemimpinan transformasional kepala madrasah, prestasi guru dan budaya belajar dalam meningkatkan mutu Madrasah Tsanawiyah Negeri Jakarta Selatan.Tarbawi, 1(01), 49-61.

[24] Newhouse, D., \& Beegle, K. (2006). The effect of school type on academic achievement evidence from Indonesia. Journal of Human Resources, 41(3), 529-557.
[25] Muhajir. (2016). The implementation of Madrasah-Based Management (MBM) at MAN 1 and MAN 2 Serang City, Banten, Indonesia-A Comparative Study. Higher Education Studies, 6(2), 11.

[26] Leithwood, K. (2016). Department-head leadership for school improvement. Leadership and Policy in Schools, 15(2), 117140.

[27] Jawas, U. (2017). The influence of socio-cultural factors on leadership practices for instructional improvement in Indonesian schools. School Leadership \& Management, 1-20.

[28] Muhammadi, N., Marzuki, S. C. b. H., \& Hussin, M. Y. b. M. (2017). Kepemimpinan transformasional kepala madrasah, prestasi guru dan budaya belajar dalam meningkatkan mutu Madrasah Tsanawiyah Negeri Jakarta Selatan.Tarbawi, 1(01), 49-61.

[29] Rosmaniar, W., \& Marzuki, S. C. b. H. (2016). Headmaster Instructional Leadership and Organizational Learning on the Quality of Madrasah and the Quality of Graduates the State Madrasah Aliyah at Jakarta Capital Region. Higher Education Studies, 6(1), 159.

[30] Harris, A., Day, C., Hopkins, D., Hadfield, M., Hargreaves, A., \& Chapman, C. (2003). Effective Leadership for School Improvement. New York: RoutledgeFalmer.

[31] Gladstone, J. S., \& Pepion, D. D. (2017). Exploring traditional Indigenous leadership concepts: A spiritual foundation for Blackfeet leadership. Leadership, 13(5), 571589.

[32] Intan, B. F. (2006). "Public Religion" and the Pancasilabased State of Indonesia: An Ethical and Sociological Analysis (Vol. 238): Peter Lang.

[33] Capwell, C. (2015). Music, Modernity, and Islam in Indonesia. This Thing Called Music: Essays in Honor of Bruno Nettl, 393.

[34] Wanandi, J. (2002). Islam in Indonesia: Its history, development and future challenges. Asia Pacific Review, 9(2), 104-112.

[35] Egel, E., \& Fry, L. W. (2017). Spiritual leadership as a model for Islamic leadership. Public Integrity, 19(1), 77-95.

[36] Dimmock, C., \& Walker, A. (2005). Educational Leadership: Culture and Diversity (M. Wilson Ed.). London: SAGE Publications Ltd.

[37] Butler, J. (2002). Antigone's claim: Kinship between life and death: Columbia University Press.

[38] Fortes, M., \& Evans-Pritchard, E. E. (2015). African political systems: Routledge.

[39] Prideaux, M. (2006). Leadership in Papua New Guinea: exploring context and barriers. Paper presented at the Proceedings of the 20th ANZAM (Australian New Zealand Academy of Management) Conference on Management: Pragmatism, Philosophy, Priorities. Rockhampton: Central Queensland University.

[40] Zakia, M. R., \& Pritasari, A. (2018). Kinship-based problems affecting the employee performance: A study case of family business in developing city in Indonesia. PEOPLE: International Journal of Social Sciences, 4(2).

[41] Allen, N., Grigsby, B., \& Peters, M. L. (2015). Does Leadership Matter? Examining the Relationship among Transformational Leadership, School Climate, and Student Achievement.International Journal of Educational Leadership Preparation, 10(2), 1-22.

[42] Allen, N., Grigsby, B., \& Peters, M. L. (2015). Does Leadership Matter? Examining the Relationship among Transformational Leadership, School Climate, and Student Achievement.International Journal of Educational Leadership Preparation, 10(2), 1-22.

[43] Zakia, M. R., \&Pritasari, A. (2018). Kinship-based problems affecting the employee performance: A study case of family business in developing city in Indonesia. PEOPLE: International Journal of Social Sciences, 4(2).Irawanto, D. W. (2009). An analysis of national culture and leadership practices in Indonesia. Journal of Diversity ManagementSecond Quarter, 4(2), 2009.

[44] Irawanto, D. W. (2009). An analysis of national culture and leadership practices in Indonesia. Journal of Diversity Management-Second Quarter, 4(2), 2009. 
[45] Irawanto, D. W. (2009). An analysis of national culture and leadership practices in Indonesia. Journal of Diversity Management-Second Quarter, 4(2), 2009.

[46] Irawanto, D. W. (2009). An analysis of national culture and leadership practices in Indonesia. Journal of Diversity Management-Second Quarter, 4(2), 2009.

[47] Rigby, J. G. (2015). Principals' sensemaking and enactment of teacher evaluation.Journal of Educational Administration, 53(3), 374-392.

[48] Wildy, H., \&Dimmock, C. (1993). Instructional leadership in primary and secondary schools in Western Australia.Journal of Educational Administration, 31(2).

[49] Day, C., Harris, A., \& Hadfield, M. (2001). Grounding knowledge of schools in stakeholder realities: A multiperspective study of effective school leaders. School Leadership \& Management, 21(1), 19-42.
[50] Hallinger, P., \& Lu, J. (2014). Modelling the effects of principal leadership and school capacity on teacher professional learning in HongKong primary schools.School Leadership \& Management, 34(5), 481-501.

[51] Attride-Stirling, J. (2001). Thematic networks: an analytic tool for qualitative research.Qualitative research, 1(3), 385405.

[52] Attride-Stirling, J. (2001). Thematic networks: an analytic tool for qualitative research.Qualitative research, 1(3), 385405 . 